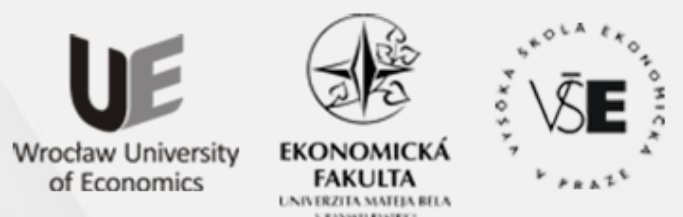

Conference Proceedings

Full TeXT PAPERS

edited by

Zofia Rusnak and Beata Zmyślona

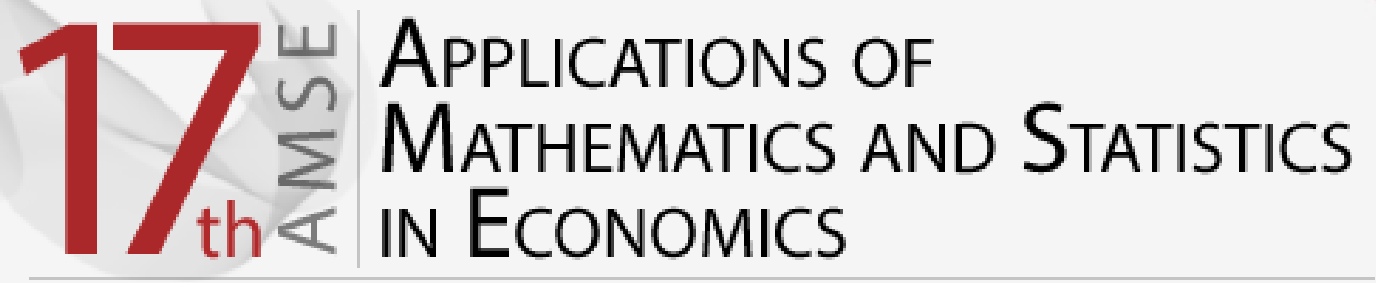

International Scientific Conference | Poland • 27-31 August 2014 
Scientific Committee

Richard Hindls, Stanislava Hronová, Rudolf Zimka, Walenty Ostasiewicz, Emília Zimková, Zofia Rusnak, Martin Bod'a

Organizing Committee

Beata Zmyślona, Cyprian Kozyra, Grzegorz Rogoziński, Kristýna Vltavská

\section{Reviewers}

Milan Bašta, Diana Bílková, Martin Bod'a, Joanna Dębicka, Tomáš Fiala, Jakub Fischer, Stanisław Heilpern, Karel Helman, Lenka Hudrlíková, Miroslav Hužvár, Nikola Kaspř́ková, Alena Kaščáková, Kamil Kladívko, Jindřich Klůfa, Pavol Král', Katarzyna Kuziak, Jana Langhamrová, Ivana Malá, Tomáš Marcinko, Luboš Marek, Miloš Maryška, Petr Mazouch, Zofia Mielecka-Kubień, Witold Miszczak, Petr Musil, Gabriela Nedelová, Walenty Ostasiewicz, Iva Pecáková, Viera Roháčová, Zofia Rusnak, Mária Stachová, Jana Špirková, Šárka Šustová, Jana Tepperová, Vladimír Úradníček, Kristýna Vltavská, Michal Vrabec, Dariusz Wawrzyniak, Henryk Zawadzki, Jaroslav Zbranek, Tomáš Zeithamer, Martin Zelený, Jan Zeman, Rudolf Zimka, Emília Zimková, Pavel Zimmermann, David Žižka

Layout

Martin Bod'a, Beata Zmyślona, Grzegorz Rogoziński

Front page design

Grzegorz Rogoziński

CD cover design

Beata Dębska

Articles published in the form submitted by the authors

All rights reserved. No part of this book may be reproduced in any form or in any means without the prior permission in writing of the Publisher

(C) Copyright by Wrocław University of Economics Wrocław 2014

ISBN 978-83-7695-421-9

Wydawnictwo Uniwersytetu Ekonomicznego we Wrocławiu

53-345 Wrocław, ul. Komandorska 118/120 www.ue.wroc.pl

Sprzedaż książek tel./fax 71 36-80-602

e-mail: econbook@ue.wroc.pl www.ksiegarnia.ue.wroc.pl 


\section{Contents}

Foreword

Diana Bílková: TL-Moments: Analogy of Classical L-Moments

Dagmar Blatná: Application of Robust Regression in the Analysis of Internet Access in European Countries

Martin Bod’a, Mária Kanderová: Rebalancing Issues in Tracking Error Variance Minimization

Martin Bod'a, Viera Roháčová: Application of Six Sigma Ideas to Timing Decisions at Financial Markets

Anton Dekrét, Rudolf Zimka: On the Price Hartwick's Task and Its Inverse in a Dynamic Model of an Economy with Exhaustible Resources

Joanna Dębicka, Agnieszka Marciniuk: Comparison of Reverse Annuity Contract and Reverse Mortgage on the Polish Market.

Petra Dotlačilová, Jitka Langhamrová: The Influence of Mortality Models for the Expected Future Life-time of Older People

Marek Ďurica, Lucia Švábová: Delta and Gamma for Chooser Options.

Vlastimil Farkašovský: New Concept of Pension Funds Performance Evaluation

Albert Gardon: The Normality of Weekly Relative Changes of the Freight Rate in Container Shipping.

Mária Grausová, Miroslav Hužvár, Jana Štrangfeldová: Healthcare Systems Efficiency in the Visegrád Group.

Stanisław Heilpern: Multiple Life Insurance - Pension Calculation

Alena Kaščáková, Gabriela Nedelová: Changes in Slovak Households' Economy

Igor Kollár, Pavol Král', Peter Laco: Methodology for Assessing Website Improvement in Corporate Environment.

Maciej Kostrzewski: Some Method of Detecting the Jump Clustering Phenomenon in Financial Time Series.

Cyprian Kozyra, Beata Zmyślona, Katarzyna Madziarska: Complementary Objective and Subjective Measures of Hospital Services Quality...

Pavol Král', Mária Stachová, Lukáš Sobíšek: Utilization of Repeatedly Measured Financial Ratios in Corporate Financial Distress Prediction in Slovakia

Ivana Malá: The Use of Finite Mixture Model for Describing Differences in Unemployment Duration

Lukáš Malec: Studying Economics and Tourism Industry Relations by Smooth Partial Least Squares Method Depending on Parameter. 
Tomáš Marcinko: Consequences of Assumption Violations Regarding Classical Location Tests.

Edyta Mazurek: The Income Tax Progression Depending on Social Insurance Contribution in Poland.

Petr Musil, Jana Kramulová, Jan Zeman: Regional Consumption Expenditures: An Important Starting Point for Regional Input-output Tables.

Katarzyna Ostasiewicz, Walenty Ostasiewicz: Good Life: From Political to Human Economy

Anna Sączewska-Piotrowska: Analysis of Poverty Transitions in Poland Using Multilevel Discrete-Time Event History Models

Martina Šimková, Petra Švarcová: Disadvantaged University Students in the Czech Republic.

Michal Široký: The Use of Short-term Business Statistics for Quarterly GDP Flash Estimates in the Czech Republic

Zdeněk Šulc, Hana Řezanková: Evaluation of Recent Similarity Measures for Categorical Data.

Lucia Švábová, Marek Ďurica: The Relationship Between the Finite Difference Method and Trinomial Trees

Kristýna Vltavská, Jaroslav Sixta: The Estimation of Final Consumption Expenditures

Lenka Vraná: Business Cycle Analysis: Tracking Turning Points

Janusz Wywiał: On Bayesian Testing in Auditing

Emília Zimková: Window Analysis of Supper-efficiency Change: Case of the Slovak Banking System ....

Beata Zmyślona: Statistical Modelling of the Impact of Diabetes on the Risk of Hospitalization 


\title{
THE RELATIONSHIP BETWEEN THE FINITE DIFFERENCE METHOD AND TRINOMIAL TREES
}

\author{
LUCIA ŠVÁBOVÁ \\ University of Žilina, Faculty of Operation and Economics of Transport and Communications, \\ Department of Quantitative Methods and Economic Informatics, Univerzitná 1, 01026 Žilina \\ email: lucia.svabova@fpedas.uniza.sk
}

\section{MAREK ĎURICA}

University of Žilina, Faculty of Operation and Economics of Transport and Communications, Department of Quantitative Methods and Economic Informatics, Univerzitná 1, 01026 Žilina email: marek.durica@fpedas.uniza.sk

\begin{abstract}
The paper deals with the relation of the Finite difference method to Trinomial Tree Approaches. The Finite difference method is numerical method which can be used for pricing many types of options. This is very useful especially in some cases of exotic options for which the analytical formula does not exist. But in some cases there could appear some inconsistencies of the results of options prices determined by this method. The Explicit finite difference method is equivalent to the Trinomial tree approach. Using the expression of the probabilities of moving the stock price in the Trinomial tree to the explicit version of Finite difference method can be explained this main problem associated with this method
\end{abstract}

Key words: finite difference method, trinomial tree, option pricing.

DOI: $10.15611 /$ amse.2014.17.28

\section{Introduction}

Setting the right price of all types of options, from basic types of vanilla options to more complicated types of exotic options, is a very important part of derivative trading. The option price must be set very precisely in order to avoid all opportunities of arbitrage profit for traders.

The Black - Scholes - Merton model for option pricing is at present one of the most famous tool for valuation of derivative contracts. Since the time of introduction Black - Scholes Merton model in 1973 the volume of option trades significantly increased and next to common European vanilla options there were introduced various kinds of more complex types of exotic options. But some types of exotic options could be so complicated and difficult to price, that the Black - Scholes model in his basis could not be used to set their price. For some types of exotic options the analytical formula for their pricing do not exists, so that their prices have to be calculated by another method. Then come into play the numerical methods. Using these methods the prices of exotic options can be estimated. One alternative of options pricing is a Finite difference method based on the Black - Scholes differential equation. In some cases this numerical method there appears some inconsistencies of solutions obtained as a result. This problem can be explained and overcome using the relationship of Finite difference method and the Trinomial tree. When we interpret the Explicit finite difference method (EFDM) as the equivalent of Trinomial tree approach, we could illustrate the main problem associated with this numerical method for option pricing and overcome it. 


\section{Types of options}

One of the basic terms which will be mentioned is undoubtedly the term option. There exist two basic types of options: a call option gives the holder the right to buy the underlying asset by a certain date in the future in a certain price; a put option on the other hand gives the holder the right to sell the underlying asset by a certain price in a certain time. The price agreed by the seller and the buyer in this contract is known as the strike price and the date, when the right given in the option will expire, is known as the expiration date or maturity. It is important to emphasize, that the option gives his holder the right to do something and the holder is not obligated to exercise this right. (Hull, 2012)

The ownership of the option provides only the right to do something and this is why the owner of the option has to pay something for conclusion of such a contract. An option buyer pays the option premium for the right to buy or sell the underlying asset, and, like the buyer of any other asset, faces carry costs. (Whaley, 2006)

European type of option can be exercised only on the expiration date itself, American type of option can be exercised at any time during the whole life of the option contract. All the simple derivatives such as American or European options are together called plain vanilla options. But besides these simple types of options there exist a large number of nonstandard products, which have been created at the over-the-counter derivatives market. These products are together termed as exotic options. These exotic products are often structured by financial institutions to meet the precise needs of their clients. Exotics have the structure different from standard calls and puts. They are designed for two reasons. The first reason is to reflect a view on potential future movements in particular market variables and to capture better the needs of traders to ensure their portfolio. And the second reason why exotic options are traded is that they appear to be more attractive tool for the traders to achieve profit. (Hull, 2012)

\subsection{Some kinds of exotic options}

One type of the exotic option is the Chooser option. The holder of the chooser option has the right to choose in given time in the future, whether his option will be call or put. That means, the holder can choose, whether he will buy or sell the underlying asset of the option. Of course, he will choose the way to maximize his profit from the transaction. The chooser option therefore provides the trader greater advantage, for which must pay a higher price. (Švábová, Ďurica, 2013)

Another type of exotic option is Barrier options, whose payoff depends on whether the underlying asset price reaches a certain level during the lifetime of the option. If the options price will reach the fixed barrier, the option will start its life, or conversely ceases to exist. Barrier options are traded in the over-the-counter markets because they are more attractive and less expensive for the traders. (Jun, 2013), (Milev, Tagliani, 2010) (Broadie, Glasserman, Kou, 1997).

Lookback options are another type of the exotic options that have their payoff dependent on the maximum or minimum asset price during the life of the option. Their payoff is the amount that the final asset price exceeds the minimum or maximum asset price achieved during the life of the option. (Leung, 2013)

Exchange options are the options to exchange one asset to another. Their holder has the right to give up one asset at given time and receive in return another asset. For example, for 
American investor, the option to buy Japanese yen with Australian dollars is the exchange option. (Gounden, O'Hara, 2009)

\section{Option pricing}

As we mentioned earlier, setting the correct price of each option traded on the financial market is very important for ensuring no arbitrage opportunities on the market. One of the basic models for pricing the financial derivatives is already mentioned Black - Scholes Merton model. The basic model was proposed in the early 1970s by Black and Scholes as a basic model of behavior of option prices which underlying asset is non - dividend paying stock. F. Black and M. Scholes herewith achieved a major breakthrough in the pricing of European stock options, because their developed model has had a huge influence on the way that traders price the derivatives. The importance of their research was recognized in 1997 and they were awarded the Nobel Prize for economics. (Hull, 2012)

The Black - Scholes model was improved by R. Merton in 1973. His approach was different from that of Black and Scholes. His approach was more general, because did not rely on some assumptions of the underlying asset. Merton includes into his model the assumption of the possibility of payment the dividend yield from the underlying share of the derivative. (Hull, 2012)

Another way to setting the price of options is using the numerical methods. There exist several types of numerical methods by which the price of most kinds of options, including more complex exotic options, which are "path dependent", can be correctly estimated. These options have their payoff function dependent on a price development of the underlying share of the option. A very useful numerical method is a method of Binomial trees, by which a price of every type of option (including exotic options which are path dependent) could be estimated. The extension of Binomial trees represents the method of Trinomial trees, which will be explained later. Second way to estimate the price of some kinds of options should be the Finite difference method. This method is based on Black - Scholes - Merton partial differential equation and represents another possibility of option pricing.

\subsection{Black - Scholes - Merton model}

The Black - Scholes - Merton differential equation is an equation which has to be satisfied by the price of every type of financial derivative, whose underlying asset is a non-dividend paying stock. In other words, by this model the prices of the options dependent on nondividend paying stock are governed.

To derive the Black - Scholes - Merton differential equation, several assumptions have to be satisfied:

- The stock price follows the geometric Brownian motion with constant parameters $\mu$ (the expected return) and $\sigma$ (the stock price volatility).

- The short selling of securities is permitted with full use of the proceeds.

- There exist no transaction costs and taxes and all the securities are perfectly divisible.

- There are no dividends paid from the underlying share during the lifetime of the derivative.

- There are no arbitrage opportunities.

- The trading with securities is continuous.

- The risk - free interest rate $r$ is constant and the same for all times of maturity. 


\section{$12 \backsim$ APPLICATIONS OF

Some of these assumptions can be relaxed, for example the parameters of the stock price process can be known functions of the time, the interest rate can be stochastic under some conditions and the underlying share can bring dividend yield. (Hull, 2012)

The key element in the Black - Scholes - Merton (BSM) analysis which leads to their pricing formulas for European call and put options is that the position in the stock and the derivative is riskless for only a very short period of time. Theoretically, the BSM model remains riskless only for an instantaneously short period of time. To remain riskless of the portfolio it must be rebalanced frequently. Because it is a true, that the return from the riskless portfolio in a very short period of time must be the risk - free interest rate. (Hull, 2012)

Under the assumptions mentioned hereabove, using the portfolio consisting of the long position in a share and short position in dependent derivative, which must be riskless during a small interval of time (so that it must instantaneously earn the same rate of return as the other short term risk - free securities), we obtain the Black - Scholes - Merton differential equation: (Hardik, 2008)

$$
\frac{\partial f}{\partial t}+\frac{\partial f}{\partial S}(r-q) S+\frac{1}{2} \frac{\partial^{2} f}{\partial S^{2}} \sigma^{2} S^{2}=r f
$$

In this equation (1) we used the Merton's approach, which allows the existence of continuous dividend yield $q$, paid from the price of the underlying asset. Hereabove in the equation (1), the following notation is used: $f$ is the price of the derivative (option), $t$ means the time, $S$ is the price of the underlying share, $r$ is risk - free interest rate, $q$ is dividend yield from the asset, $\sigma$ is the stock price volatility.

This equation has infinite number of solutions based on the selected initial conditions. For a European call option the solution of the BSM equation is a formula: (Hull, 2012)

$$
c=S e^{-q T} N\left(d_{1}\right)-X e^{-r T} N\left(d_{2}\right),
$$

where $N\left(d_{1}\right)$ and $N\left(d_{2}\right)$ are the values of the distribution function of a standard normally distributed random variable in $d_{l}$ and $d_{2}$ given by

$$
d_{1,2}=\frac{\ln \frac{S}{X}+\left(r-q \pm \frac{\sigma^{2}}{2}\right) T}{\sigma \sqrt{T}} .
$$

The notation used is valid as before, here in (2) and (3) moreover $X$ is the strike price. The formula (2) is the most famous solution of the BSM differential equation (1) and is known as the Black - Scholes - Merton model (pricing formulas) for the price of European call options. The notation is as before, in addition here $T$ is the time of maturity of the option.

\subsection{Trinomial tree method}

Trinomial trees can be used as an alternative approach to Binomial trees. Binomial tree is a very useful and popular technique for pricing options. It represents the asset price movements in the form of a tree, where different possible paths of the stock price over the life of the option are shown. The underlying assumption is that the stock price follows a random walk. Than in each time step, it has a certain probability of moving up by a certain percentage amount and a certain probability of moving down by a certain percentage amount. In the limit, 


\section{APPLICATIONS OF \\ Mathematics and Statistics \\ the IN ECONOMICS}

International Scientific Conference | Poland • 27-31 August 2014

as the time step becomes shorter, this Binomial tree model becomes the same as Black Scholes - Merton model mentioned hereabove. (Hull, 2012)

The Trinomial tree approach is the enlargement of this consideration. More, in Trinomial tree we expect that the stock price can not only increase or decrease by a certain percentage amount with a certain probability, but can also remain at the same level. The general form of the Trinomial tree is shown in following figure.

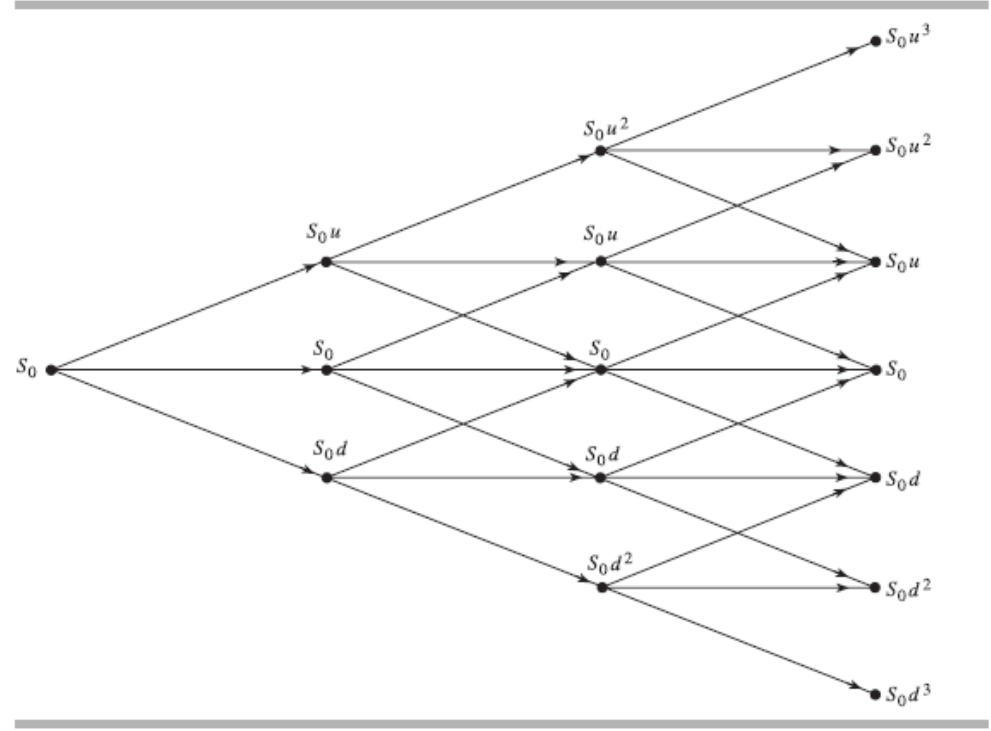

Figure 1 Trinomial stock price tree Source: Hull, 2012.

Calculations for a Trinomial tree are the same as those for Binomial tree. We move from the end of the tree to the beginning. In each time interval $\Delta t$ the price of the underlying asset moves from its initial value $S_{0}$ to one of two new values, $S_{u}=S_{0} \cdot u$ and $S_{d}=S_{0} \cdot d$, or stay the same $S_{0}$, where $u>1$ and $0<d<1$. The percentage increase in the stock price when there is an "up" movement is $u-1$; the percentage decrease when there is a "down" movement is $1-d$. If the stock price moves up to $S_{u}=S_{0} \cdot u$, we suppose that the payoff from the option is $f_{u}$. If the stock price moves down to $S_{d}=S_{0} \cdot d$, we suppose the payoff from the option is $f_{d}$. And if the stock price stay the same $S_{0}$, we suppose the payoff from the option is $f_{m}$. (Hull, 2012)

Then in next step in the tree, each price of the underlying asset can move to one of three positions: up, down or middle. So that in each time interval the value of underlying asset in next time step is the value from step before, multiplied by coefficient $u$ (up movement) or $d$ (down movement) or stay the same (middle).

At each node we calculate the value of exercising the option and the value of continuing it. The value of continuing the option is given by

$$
f=e^{-r \Delta t}\left(p_{u} f_{u}+p_{m} f_{m}+p_{d} f_{d}\right),
$$

where $f_{u}, f_{m}$ and $f_{d}$ are the values of the option in next up, middle and down nodes, respectively and $p_{u}, p_{m}$ and $p_{d}$ are the probabilities of up, middle and down movements, respectively. (Hull, 2012) 
By repeating the calculation of option value in tree nodes from right to left we get a numerical estimate of the option price obtained by Trinomial trees method.

\subsection{Finite difference method}

The Black - Scholes - Merton equation is a partial differential equation which is valid throughout the whole given domain. The solution of the differential equation will be significantly easier if we reduce the domain of definition into a finite number of points. This consideration is the keynote of Finite difference method.

Suppose that the life of the option is $T$. We divide the whole option lifetime into $N$ equally spaced intervals of length $\Delta t$. Then suppose that a maximum stock price is $S_{\max }$ which is so high that, when it is reached, the corresponding put option has virtually no value. We divide the whole stock price interval from 0 to $S_{\max }$ into $M$ equally spaced subintervals with length $\Delta S$. Than we reduce all the considerations into only grid points, which we define as the time points and stock price points. The variable $f_{i, j}$ will denote the value of the option in time $i \Delta t$ with stock price $j \Delta S$. The whole grid consists of $(N+1)(M+1)$ points. (Hull, 2012)

The keynote the Finite difference method is to replace the partial derivations in the BSM differential equation (1) with given differences. Every interior point of the grid has the value of the partial differential equations approximated with the differences of the values of the option in neighboring nodes. There exist two basic ways to use the Finite difference method, depending on the differences used:

- The Implicit finite difference method uses the approximations, which by being substituted to equation (1) leads to a system of equations for the unknown value of the derivative at internal points of the grid. By repeating the procedure for solving the system we obtain the derivative price at the time zero.

- The Explicit finite difference method uses such approximations of partial derivations, which by being substituted to equation (1) leads to the formula for calculating the price of the derivative at that point directly:

$$
f_{i, j}=\frac{2 \Delta S^{2} f_{i+1, j}+\Delta t \Delta S(r-q) S_{j}\left(f_{i+1, j+1}-f_{i+1, j-1}\right)+\sigma^{2} S_{j}{ }^{2} \Delta t\left(f_{i+1, j+1}+f_{i+1, j-1}-2 f_{i+1, j}\right)}{2 r \Delta t \Delta S^{2}+2 \Delta S^{2}}
$$

Similarly like in the Trinomial tree, we move from the end of the grid to the beginning. At each node we calculate the value of the derivative using the expression (5). The main assumption is that the values of the option in the endpoints of the grid are known:

- at the time of expiration, the value of the option is given by the payoff function,

- for a share with zero prices the call option has zero prices too,

- for a share with maximum price $S_{\max }$ the corresponding put option has zero value, so that the price of call option follows from the put - call parity. (Švábová, Ďurica, 2012)

The equation (5) gives the relationship between three different values of the option at time $i \Delta t$ (that are the points $f_{i, j-1}, f_{i, j}$ and $\left.f_{i, j+1}\right)$ and one value of the option in time $(i+1) \Delta t$ (that is the point $f_{i+1, j}$ ) as shown in following figure of the EFDM. 


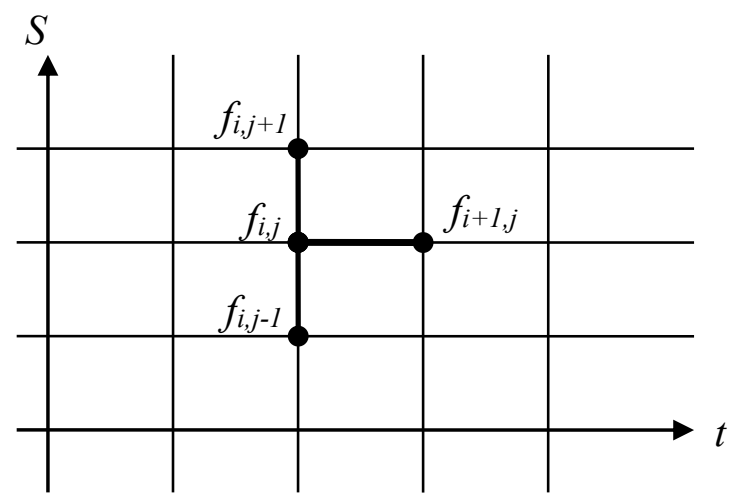

Figure 2 Explicit finite difference method grid Source: Own elaboration.

\section{Relation of the Explicit finite difference method to Trinomial tree approach}

The EFDM is equivalent to the Trinomial tree approach. We could reformulate the expression (5) by

$$
f_{i, j}=a_{j}^{*} f_{i+1, j-1}+b_{j}^{*} f_{i+1, j}+c_{j}^{*} f_{i+1, j+1}
$$

where

$$
\begin{gathered}
a_{j}^{*}=\frac{1}{1+r \Delta t}\left(-\frac{1}{2}(r-q) j \Delta t+\frac{1}{2} \sigma^{2} j^{2} \Delta t\right), \\
b_{j}^{*}=\frac{1}{1+r \Delta t}\left(1-\sigma^{2} j^{2} \Delta t\right), \\
c_{j}^{*}=\frac{1}{1+r \Delta t}\left(\frac{1}{2}(r-q) j \Delta t+\frac{1}{2} \sigma^{2} j^{2} \Delta t\right) .
\end{gathered}
$$

In these expressions we can interpret the terms as follows: (Hull, 2012)

- $\quad p_{d}^{*}=-\frac{1}{2}(r-q) j \Delta t+\frac{1}{2} \sigma^{2} j^{2} \Delta t$ is probability of stock price decreasing from $j \Delta S$ to $(j-1) \Delta S$ in time $\Delta t$,

- $p_{m}^{*}=1-\sigma^{2} j^{2} \Delta t$ is probability of stock price remaining unchanged at $j \Delta S$ in time $\Delta t$,

- $p_{u}^{*}=\frac{1}{2}(r-q) j \Delta t+\frac{1}{2} \sigma^{2} j^{2} \Delta t$ is probability of stock price increasing from $j \Delta S$ to $(j-1) \Delta S$ in time $\Delta t$.

The interpretation is illustrated in following figure. 


\section{APPLICATIONS OF \\ Mathematics and Statistics \\ IN ECONOMICS}

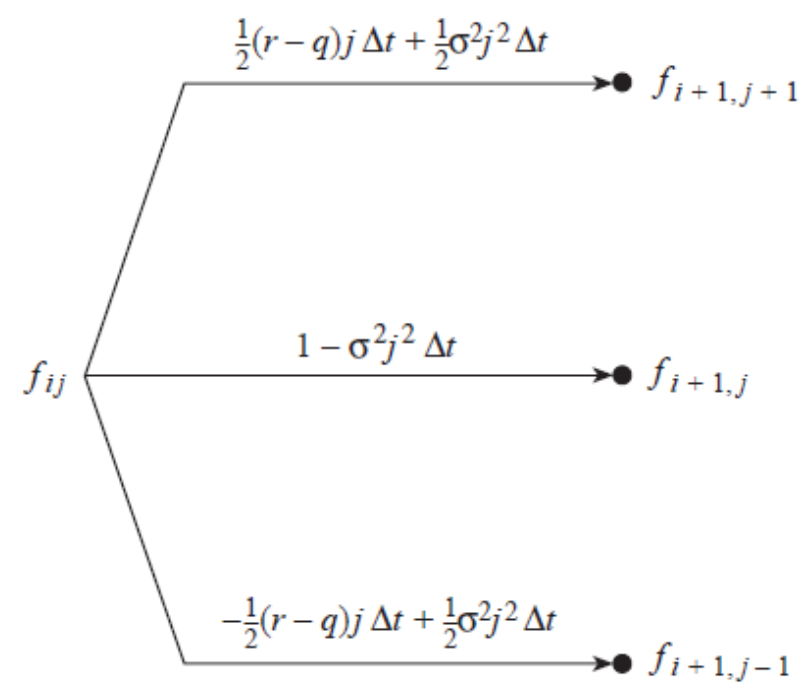

Figure 3 Interpretation of Explicit finite difference method as a Trinomial tree Source: Hull, 2012.

Since these three expressions $p_{d}^{*}, p_{m}^{*}$ and $p_{u}^{*}$ are probabilities, they sum to unity. Because these three probabilities appear in the expression for calculating the price of the option by EFDM (6), they can be used to illustrate the main problem associated with this method. And here comes the main substance of the relationship between these two numerical methods.

For the Explicit version of the FDM to work well, the three probabilities should all be positive. But for some values of input parameters used for option pricing by EFDM, the probabilities will sum to unity indeed, but some of them should be negative, which could lead to incorrect results of numerical estimate of the option price obtained by EFDM. Because the probabilities in the associated Trinomial tree may be negative, the EFDM does not necessarily produce the results that converge to the solution of BSM differential equation. (Hull, 2012)

We will describe this situation in the example.

Let us have European call option, which will expire 1 year later. The option has the strike price 100 and the underlying asset price is 100 too. The risk - free interest rate is $5 \%$ and the dividend yield paid from the asset is $2 \%$. The volatility of the option is $14 \%$. We will price this option by FDM using the method suggested in (Švábová, 2011). The grid used for the valuation has 100 subintervals of stock price interval, where maximum possible stock price is 200. Time interval from 0 to maturity in 1 year will be divided into more subintervals: from 2 doubled to 1024. As we mentioned hereabove, in some steps of using the EFDM, there appear some inconsistencies: some of the results are negative or are too big numbers to be properly results. Using the interpretation of the equation (6) with the probabilities $p_{d}^{*}, p_{m}^{*}$ and $p_{u}^{*}$ of moving the stock price down, unchanged and up in the grid we could find the points in the grid, where the inconsistencies could appear.

In the example described hereabove the values of the probability $p_{m}^{*}$ are sometimes negative. The others probabilities $p_{d}^{*}$ and $p_{u}^{*}$ are positive numbers, but their values exceed 1 , so that their interpretation as probabilities is not possible in this case. The incorrect values of the probabilities $p_{m}^{*}$ for various values of $\Delta t$ depending on the step $j$ in the direction of axis $S$ (stock prices) are shown in following figure. 


\section{A Amataras of of \\ Mathematics and Statistics \\ the IN ECONOMICS}

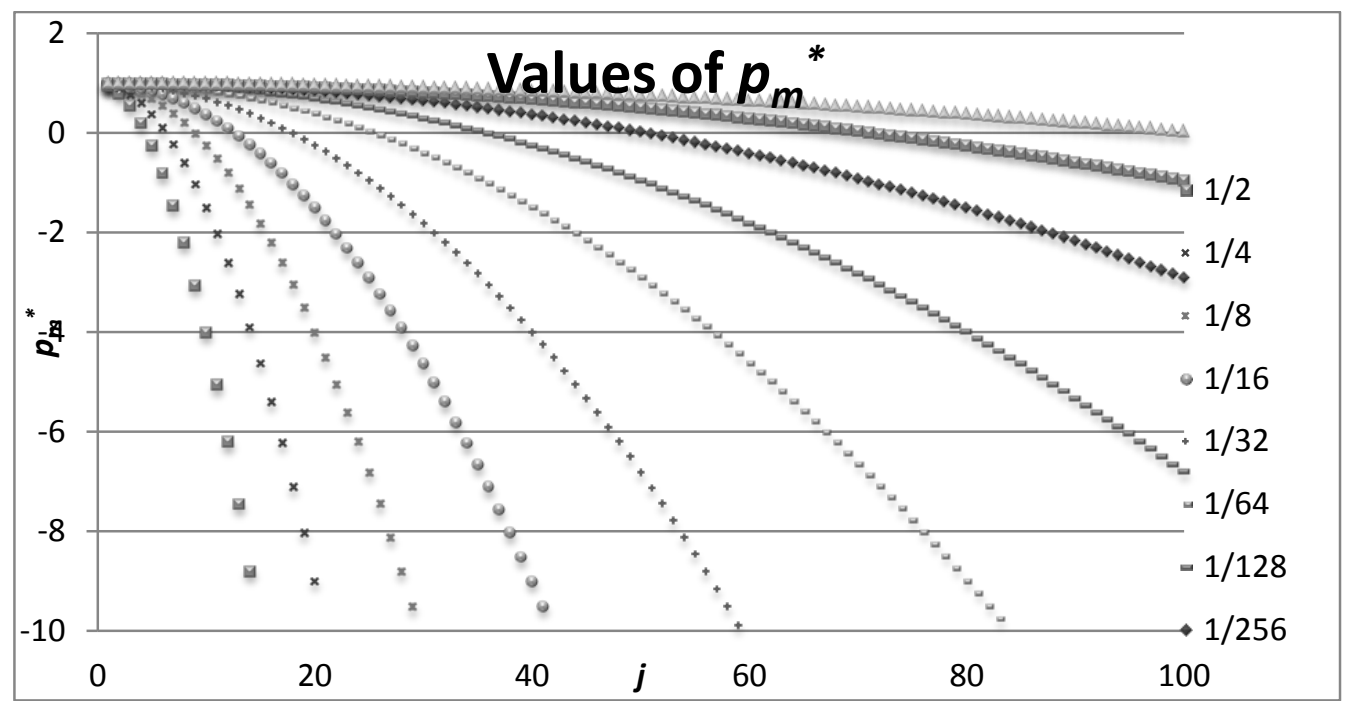

Figure 4 Non-properly values of probabilities $p_{m}^{*}$ for various $\Delta t$ Source: Own elaboration.

As we can see in the picture hereabove, for $\Delta t=1 / 1024$ the probabilities $p_{m}^{*}$ have correct values: are positive and smaller than 1 . The larger the length of the time interval is, the more non-properly results appear. For $\Delta t=1 / 512$ the inconsistencies appears for $j \geq 72$, that is for $S \geq 144$ in this example. Our price of the underlying asset is $S=100$, which corresponds to $j=50$. In this division of time interval the price of the call option is correctly estimated, because this price is above the non-properly values of $p_{m}^{*}$. For smaller number of subintervals in time interval of option life there appears increasingly more values of probabilities- $p_{m}^{*}$, which are negative. In following table the values of $j$ and corresponding $S$, from which the $p_{m}^{*}$ are non-properly valued for various length of $\Delta t$ are written.

Table 1 .Values of $j$ and corresponding stock price $S$ with $p_{m}^{*}$ negative.

\begin{tabular}{c|ccccccccc}
\hline$\Delta t$ & $1 / 512$ & $1 / 256$ & $1 / 128$ & $1 / 64$ & $1 / 32$ & $1 / 16$ & $1 / 8$ & $1 / 4$ & $1 / 2$ \\
\hline$j$ & $\geq 72$ & $\geq 51$ & $\geq 36$ & $\geq 26$ & $\geq 18$ & $\geq 13$ & $\geq 9$ & $\geq 7$ & $\geq 5$ \\
\hline$S$ & $\geq 144$ & $\geq 102$ & $\geq 72$ & $\geq 52$ & $\geq 36$ & $\geq 26$ & $\geq 18$ & $\geq 14$ & $\geq 10$ \\
\hline
\end{tabular}

As we mentioned, for $\Delta t=1 / 1024$ have all the probabilities $p_{m}^{*}$ properly values, so that the call option price is correctly estimated. For $\Delta t=1 / 512$ is stock price $S=100$ above the corresponding points with negative values of $p_{m}^{*}$, so here the call option is still correctly valued and the same is for $\Delta t=1 / 256$. But for smaller number of grid points in the direction of timeline there appears non-properly results from EFDM - some results are negative or are too big to be correct option price. In following table the estimated values for this call option with given parameters obtained from EFDM are shown. As we can see the estimates are correct just for $\Delta t=1 / 256$ and smaller from those listed. 
Table 2.Estimated prices of call option from EFDM.

\begin{tabular}{c|ccccccccccc}
\hline $\begin{array}{c}\text { Number of time } \\
\text { subintervals }\end{array}$ & 2 & 4 & 8 & 16 & 32 & 64 & 128 & 256 & 512 & 1024 \\
\hline Call option price & $<0$ & $<0$ & $<0$ & $<0$ & $<0$ & 35331,97 & 2477,0049 & 7,0026 & 7,0015 & 7,0009 \\
\hline
\end{tabular}

Source: Own elaboration.

So that in this example it is necessary to choose the number of time subintervals more than 256 from those listed. Then we will get properly results which will be close to real price of the call option calculated from BSM formula (2) which is $c=7,0142$.

By this relationship between the Trinomial trees and Explicit finite difference method we could choose the appropriate number of grid points to get properly estimated results of option prices.

\section{Conclusion}

Explicit finite difference method is a numerical method which can be used for option price estimating. The main problem associated with this method is that for some values of selected option parameters and the number of subintervals in the direction of timeline and stock price there could appear the results, which sure cannot be correct, because are negative or too big values to be correct prices. Than it is a problem to choose the right density of the grid in EFDM to obtain correct results of the option prices estimates. This problem can be solved by using the relationship between the EFDM and Trinomial trees. Than we could interpret the expression for calculating the option prices in grid points using the probabilities of moving the stock price up, unchanged and down. Whereas this statement includes probabilities, we have the conditions, from which we could determine the right grid density. Than the results obtained from EFDM are correct and converge to the right price of the option. In this paper we represented this relationship and its use on the European call option, but it could be of course used also for some more complex exotic option.

\section{Acknowledgements}

This paper was designed in response to the project co-funded by the EU called "The quality of education and human resources development as pillars of a knowledge society at the Faculty PEDAS, ITMS 26110230083".

\section{References}

1. BROADIE, M., GLASSERMAN, P., KOU, S. Continuity correction for discrete barrier options. In Mathematical Finance, 1997, vol. 7, pp. 325-349.

2. GOUNDEN, S., O'HARA, J.G. 2009. An Analytic Formula for the Price of American Exchange Options. [cit. 01-04-2014] http://papers.ssrn.com/sol3/papers.cfm?abstract_ $\mathrm{id}=1403746$

3. HARDIK, D. 2008. Numerical Method for Pricing Exotic Options. MSc. Thesis. [cit. 0204-2014] http://www3.imperial.ac.uk/pls/portallive/docs/1/55071696.PDF

4. HULL, J. C. 2012. Options, Futures, and Other Derivatives. $8^{\text {th }}$ ed. New York: Pearson Prentice Hall. 2012. 847 pp. ISBN 978-0-273-75907-2

5. JUN, D. 2013. Continuity correction for discrete barrier options with two barriers. In Journal of Computational and Applied Mathematics, 2013, vol. 1, iss. 237, pp. 520-528. 
6. LEUNG, KS. 2013. An analytic pricing formula for lookback options under stochastic volatility. In Applied Mathematics Letters, 2013, vol. 1, iss. 26, 145-149.

7. MILEV, M., TAGLIANI, A. 2010. Numerical valuation of discrete double barrier options. In Journal of Computational and Applied Mathematics, 2010, vol. 10, iss. 233, 2468-2480.

8. ŠVÁBOVÁ, L. 2011. Using of the Finite Difference Method for European Call Option Pricing. In Proceedings of the $8^{\text {th }}$ International Scientific Conference Actuarial Science in theory and in practice 2011, 115-122.

9. ŠVÁBOVÁ, L., ĎURICA, M. 2013. Using the finite difference method for Chooser option pricing. In Proceedings of $9 \mathrm{t}^{\mathrm{h}}$ international scientific conference Financial management of firms and financial institutions. 2013. ISBN 978-80-248-3172-5. pp. 943950.

10. ŠVÁBOVÁ, L., ĎURICA, M. 2012. Asian option pricing. In Proceedings of $9^{\text {th }}$ international scientific conference Managing and Modeling of Financial Risks. 2012. ISBN -80-248-2835-0. pp. 600-609.

11. WHALEY, R. E. 2006. Derivatives: Markets, Valuation, and Risk Management. New Yersey: John Wiley \& Sons, 2006. pp. 930. ISBN 978-0-471-78632-0. 